\title{
A Study of Social Learning for 8th - grade Students on Studying English at SMP Muhammadiyah 12 GKB
}

\author{
Erik Okta Qurniawan \\ SMP Muhammadiyah 12 Gresik, Jawa Timur, Indonesia \\ J1. Sumatra No. 101 GKB Gresik \\ E-mail: qurniawane@gmail.com \\ Khoirul Anwar \\ Universitas Muhammadiyah Gresik, Jawa Timur, Indonesia \\ Jl. Sumatra No. 101 GKB Gresik \\ E-mail: khoirulanwar@umg.ac.id \\ Candra Hadi Asmana \\ Universitas Muhammadiyah Gresik, Jawa Timur, Indonesia \\ J1. Sumatra No. 101 GKB Gresik \\ E-mail: candrafkip@umg.ac.id
}

\begin{abstract}
Social learning is an essential learning as a part of activities to change the behavior through public action. This study investigates a study of social learning for 8th grade on studying English at SMP Muhammadiyah 12 GKB. To guide students learning, the teacher serves the activity through modelling so that teacher must have known the students' need before going to the class. It includes observational learning for the students in which affected their attention process, retention process, motor reproduction process, and also reinforcement process. It adopted theory of bandura toward social learning. The subject research is 32 students at 8 th

grade, it uses descriptive qualitative research during the observation and interview. The result of study described the transcript of conversation that involved in the classroom activity. Therefore this study aims to show social learning for 8th grade students on studying English at SMP Muhammadiyah 12 GKB
\end{abstract}

Key words: Basic Writing, learning material, digital module, Android, learning media.

\section{Introduction}

The study shows that the implementing of students' behavior which includes a cognitive aspect through social learning. Because learning is a part of activities that influence students to change their character as human beings. According to Tarsono (2010) said that people are individual beings and social beings. On the other hand, every person has different characters as individual beings and most of them can be affected each other it means that as social beings people are not able to do nothing without any someone's help. According to S, Deaton (2015) defined that the world well-aware that people did not learn in a vacuum, human experience told a different story, one of interaction and cognitive consequence. Besides that, this study considers a social problem which is according to Jackson, T.C.B. (2017) stated that a socially constructed way of seeing certain conditions that provide a claim to change through public actions. Thus, a social problem is not separate from everyday interactions of students in a classroom society and also not separate from the operations, goals, and objectives of learning.

In general, the problem with using First Language can hinder students in mastering English. According to Jenna, M. S. \& Anna, M. S. (2018) said that frequent use of the first language delays the learning of English, the fluency in which they view as essential for EFL students to succeed in their education and lives. This view is contradicted by empirical evidence indicating that allowing EFL students to think and use their first language produces a positive, rather than negative, the effect on individual learning (De Angelis \&Dewaele, 2009). 
The environment is part of students' first language that includes the important factors in supporting students English learning levels. In which according to G. Murray (2017) stated that a comfortable place is one of the social forms that can influence students to practice in nascent oral communication skills. On the other hand, informal social interaction also is able to give a space tool for learning. Thus, knowledge is divided into 2 factors, that is, according to Bandura's theory (1969) defined that cognitive as an internal factor and also surrounding students' environment in supporting their external factor. So, in Bandura's theory shows the role of cognitive and behavior of the students in order to reach the knowledge. Not only that, according to Piaget (1985) explained that human beings construct knowledge byinterpreting experiences of their physical environment, in particular when cognitive conflicts occur. Therefore, this study can be concluded that in general cognitive can be constructed through students' learning situations by a few overlook the teacher' $s$ teaching in the classroom practice which is a place where students to perform a learning process during they have a target on the subject matter. The previous research had already investigated the impact of environment toward learning English with social learning. According to Garold, M. (2017) investigated about Autonomy and Complexity in Social Learning Space Management which determines the identification of opportunities for language learning available in this space. In this research, garold assumed that to support the complexities of social learning space need some elements which can be developed students active involvements toward their learning environment, it means that by giving some affordances are able to encourage students autonomy through the completeness of all features and space design which is showed a good feedback toward students environment. In addition, the researcher decides to choose SMP Muhammadiyah 12 GKB as the research target which based on many considerations related to the potential learning process possessed by. Besides that, this school is one of the best schools that provide quality teaching to seed their students to be better to change students

\section{Literature Review}

According to Shirley, W., \& E., J., Highwood. (2018) stated that essentially social learning is a system where the learning occurs with and from others. According to Bingham \& Conner (2015) stated that social learning theory has its roots in sociology, behavior modification, and psychology with an early focus on learning appropriate social behavior by imitating others. Therefore, social learning is able to change students behavior in imitating others during it occurs at the school. As simply social learners are individuals that live at the expense of the population, exploiting the information, skills, and resources acquired, devised, or discovered through social learning but contributing no new information themselves. Meanwhile, according to Umar D. (2018) stated that social studies education can provide a significant contribution in overcoming social problems, because social studies education has a function and role in improving human resources to obtain knowledge about human dignity and values as social beings, the ability to apply that knowledge and be able to behave based on values and norms so able to live in a community. On the other hand, Learning can be viewed as a journey through landscapes of practices. Kohlberg (1963) define the terms identification for matching behavior that is presumed similarity and the construct imitation for instrumental responses supported by extrinsic rewards. Matching behavior occurring in the presence of the model, while endowing identification with the performance of the model's behavior in the latter's absence, (Kohlberg, 1963; Mowrer, 1950). Learning would be exceedingly laborious, not to mention hazardous, if people had to rely solely on the effects of their own actions to inform them what to do (Bandura, 1977). It requires to use the appropriate strategy to maximize social learning on studying English. According to bandura (1986) said that Modelling engages students and encourages learning. According to Eggen and Kauchak (2001) stated that modelling is an instructional strategy in which the teacher demonstrates a new concept or approach to learning and students learn by observing. Because according to Haston (2007) said that whenever a teacher demonstrates a concept for a student, that teacher is modelling.

This study determines that modeling is an important ways of students in processing their learning at classroom, according to bandura said that the basic idea of learning can occur through observation or example rather than solely by direct reinforcement. A behavior modification technique that involves observing the behavior of others (the models) and participating with them in performing the desired behavior.

Modeling a behavior modification technique that involves observing the behavior of others (the models) and participating with them in performing the desired behavior. According to Suzanne and Laura Most human behavior learned observationally through modelling, a teacher can model by using visual, auditory, tactile, and/or kinesthetic instructional techniques. The previous researcher has shown that modelling can be used across disciplines and in all year and ability level classroom. A model can provide examples of what is expected of the students in terms of work and behavior.

Based on Albert Bandura's theories (1969) regarding cognitive and behavioral processes are divided into 4 categories, that is, Attention, it means that people who learn from a model when they recognize and pay attention to its critical features. According to Montessori, M. (2016) said that attention refers to the stimulus that captures the child's focus or can be the attention propelled be an "internal impulse" Additionally, attention process consists of some indicators that describe student who concerned the social learning are able to get attention on teacher stimulus through some strategies that is 1) see teacher' explanation, 2) asks question to the teacher, and 3) show a little bit imitation. Retention, it means 
that how well the individual remembers the model's action. According to Brittany, C. (2013) explained that 'Retention' refers to the length of time that students continue to study at a particular institution. Additionally, student will be categorized into the indicator, that is, those who are able to answer the teacher question in which already defined them.

Motor reproduction, it means that after the students who observing the model, they must imitate the model action. People might pay attention to a model and encode what they have seen, but limitations in motor development might make it difficult for them to reproduce the model's action.

Reinforcement, it means that motivated to exhibit the modeled behavior if positive incentives or rewards are provided. Additionally, the students will be categorized into several indicators, that is, those who show expression (happy, sad, embarrassed, and get angry), and keep trying to answer correctly.

In the case of the previous study, many previous researchers investigated the use of the social learning process in the class. Research from Shawn R. Tucker (2018) examined Social Learning via Improved Daily Writing Assignments, Implementation of Study Groups, and Well-Structured Daily Class Discussions. He studied 30 students from state universities in the southeastern part of America. In his research, he divided the groups according to the numerical order mentioned by the students, then he asked students to understand each different character in the novel that was shared in each group. After students gather insights about the characters in the novel, then shared by discussing it with the group members. As a result, indirectly the students who learn through social learning as a group discussion can develop insights in writing assignments in which group friends will provideconvenience in improving students' ability to analyze what has been observed by others through discussion methods.

Therefore, related to the previous research above, it had same variables of social learning through modeling. But this study emphasizes on observing the way of teaching through social learning affected classroom practice, meanwhile there is no research showed the condition of social learning conducted on studying English. The subject was also different which the researcher interest on descriptively toward English learning activity within social learning for junior high school. Not only that to understand deeply on how a student predicts in imitating teacher's modeling in studying English to measure strengths and weakness of their English skill, the researcher observes the step for 3 days. The role of a teacher as facilitator gives a big impact so by an interview in some questions concerned with goals, theory intelligence, metacognitive, self-regulation, assessment, objectives, purposes, strategies, value and interest, communities of learner or strategic help seeking that covered the observational process within social learning at the classroom

This research was classified as a qualitative because the data would be shown in description form and about social learning in EFL Classes. In this study, the researcher uses analyze descriptive qualitative because in this study try to analyze the students' social learning in classroom practice through studying English. The researcher uses observation in which give to students who related bandura's theory in social learning, further instruments use the interview in which clarify to the teacher who develops students' English skill through the observational process, imitation process, and modeling process.

The process of this design is used descriptive design. The researcher uses descriptive means in order to fully process the information and convey it to those interested in the study. The researcher needs to have a list of interviews to analyze the teacher's questioning. The researcher also uses an interview for the teacher in order to get some data that related to the teacher questioning that the researcher given whether the teacher has good intending to elaborate on students' skills through social learning.

\section{Methods}

In this study, the researcher chooses SMP Muhammdiyah 12 GKB for 8th-grade students because the students who will be investigated have the requirements of social learning. The teacher confirmed that every student seems to have an interest while teaching and learning activities through modeling classes. The teacher also prioritizes enjoyable learning in which is showed students need even though the students have different characters and cognitive behavior in the classroom. Therefore teachers believe that it will improve their attention when the students focus on the teacher's explanation and instruction. There are 20 male and 12 female ( $\mathrm{N}=32$ students). In this study, the researcher as the observer non-participant which will be monitoring toward action and responses of classroom practice at 8th-grade class. In every last meeting, the researcher will interview the teacher related to 4 main indicators include social learning that has been conducted at classroom activities. So that it expected that teaching and learning activities through social learning can be correlated with one another within the teacher's modeling and students' response in the classroom.

The researcher would take several steps to collect the data, in which can be described below: the first, the researcher will observe the activity in classroom, then the researcher will come to the teacher to interview directly related to the activity in classes, which held for three days due to the researcher's observations and teacher interviews related to the characteristics of students who were taught to have a high desire to learn, which is demonstrated through the interaction 
of student to students and students to teacher during learning English in class. Therefore, the researcher only provides less than four meetings to obtain student observation data during the study.

\section{Findings}

The researcher discusses the result of observation and interview which related to the problem of statements presented in chapter one. The problem statements about how is social learning for 8th grade in studying English at SMP Muhammadiyah 12 GKB. In this study, the researcher used the descriptive qualitative design that presents an analysis of general discussion in students studying English through social learning.

1. Attention

This activity was conducted to show students' focus on the teacher's explanation, imitation, and taking note. The students showed the variety of responses can be described as follow: First, it is shown in the first observation on Monday, July 15th, 2019. When the teacher expressed the words of giving appreciation by using gesture expressively, the students seemed to imitate the words with slowly sound. But a quarter of them seem silent in which means need more time to deeply understand the teacher explanation. Moreover, the other students preferred taking note after the teacher gave an example of how to express someoneappreciation tense that compiled it in one chapter. He cont extually. $\quad$ explained it clearly by showing the

Second, it shown in first observation on Monday, July 15th, 2019, after the teacher made a table of appreciation in assignment session, he adhered 5 pieces of paper that content of some information toward someone's names who had been successful in their life, then the students must collect the information as much as possible which is make sure the students produce their ability in getting information through interaction with one another, The students seemed to focus on the teacher instruction, they would like to deeply understand before getting the information toward someone who included the table. After that, there was interaction among students. Therefore, this teaching strategy could reconstruct the student's confidences, especially in asking and giving appreciation. The third, it is shown in second observation on Tuesday, July 16th, 2019 when the teacher brought the object learning then he showed the way of asking and giving an opinion, the students seem direct understand how to express ask someone opinion. Third, it is shown in second observation on Monday, July 15th, 2019, when the teacher drew a picture on whiteboard he asked the students to draw their picture at least 20 minutes, The students seemed variety responses, that is, 10 students were talking with one another even though the teacher still ongoing the explain, the other students seemed to write on their book and almost a half of them paid attention to the teacher. The fourth, it conducted on Monday, July 22nd, 2019. When the teacher reminded the students such kind of tenses, involved present tense, continuous tense, and past definition, function, and students' real life examples, Based on students' reactions after being explained, most of them pay attention to the teacher's explanation in detail but not a few of the students who decided to take notes after the teacher wrote the explanation on the board.

The fifth, it conducted on Monday, July

22nd, 2019. When the teacher gave some examples in each function of present tense above,

In this case the researcher found at least

4 students who wrote it down on their paper, such kind of student 28, she wrote the pattern:

She argued that it helped her in reminding the way on how to make a sentence in present tense correctly.Therefore, according to the descriptive above it could be concluded that the indicators of students' attention appeared at this class, in which proved by most students who listened to the teacher meanwhile they would try to understand the explanation and

12 of 32 students preferred to write or take a note on their book involved teacher's explanation. So during three meetings, the students totally dominant showed their attention toward teacher explanation and instruction.

\section{Retention}

This activity was conducted to show students memorize related to the explanation. The students showed the variety of responses can be described as follow: First, it is shown in first observation on Monday, July 15th, 2019, when the teacher just gave a sign like make a letter " $T$ " with his hands, all students seemed to understand what the teacher's mean.

The teacher showed students some sign that indicated the English word at previously before this research conducted. So just did like that teacher believed that it could be representative him to tell the students to be silent and pay attention. Second, it is shown in first observation on Monday, July 15th, 2019, when the teacher had already explained the material then asked the students to retell or re-example the expression of asking and giving appreciation, the students seem showed variety responses.

In this case, students who were chosen by teacher firstly and after it could not express give someone appreciation then teacher canceled and gave a chance to the others. It caused them to spend the time that given the teacher for 3 seconds after chosen it,It caused his classmates said "sosis" he knew the word indirectly as a clue then he said "so nice" after it.

So it was unclear for the researcher but the teacher appreciated them which is they could give someone appreciation spontaneously. According to the activities above ensured that the students were able to share their feeling 
expressively toward appreciate someone's effort. So that students knew the meaning deeply how to respect someone then appreciate it in real life. The third, it shown in second observation on Tuesday, July 16th, 2019 when the teacher brought the book then asked the students, students seem variety responses, There was a student need to think aloud more than twenty seconds like students (3) she seems lost the word on her mind that will be expressed it, but suddenly she response it after teacher moves away from her, Therefore it could be concluded that in this meeting the teacher could use the other object to elaborate their appreciation. The third, it was shown in third observation on Monday, July 22nd, 2019. The teacher reinforced students' memory by asking some of them toward the explanation about tenses. Furthermore, teacher lured the students through the discussion these questions. Then he looked at student 11 initiated answering the question, The teacher did not only tell the information theoretically but the researcher assumed that he also brought students back to their real life contextually through the example with hope asked the students to know more how it should be done by the students in learning present tense correctly. In other cases, the teacher had three word of infinitive verb while conducting students' memory through arranging the text. Teacher attempted students who wanted to guess the correct and incorrect sentence. Then, student 9 initiated to answer it,The researcher argued that what teacher planned were going to help the student reminded their memory to remember teacher's explanation after it. This activity very useful which could provoke students' initiative in expressing the correct pattern on present tense.

The fourth retention, it shown on next to topic at the same day on July 22nd, 2019. Teacher still used the same ways on provoke student.Then, teacher asked student 30 must choose one of her friends to make 1 sentence on number 2 (avoid). Therefore, according to the descriptive above it could be concluded that the indicators of students' retention appeared at this class, in which proved by most students who were being asked a question from teacher related the material, the students were able to answer correctly. It showed that from 20 times attempts teacher ask in different students, just 3 of them could not answer but the other totally dominant had good memory toward how to ask and give appreciation based on teacher's instruction or example.

\section{Motor reproduction}

This activity was conducted to instruct the students to practice the theory had been they learned. The students showed the variety of responses can be described as follow:

First, it is shown in first observation on Monday, July 15th, 2019, after the teacher instructed the students, the teacher asked to walk around suitable in getting information about the picture that adhered at the wall. Most of the students seemed to enjoy the activity, they read the text together to get the information easier. Sometimes the teacher asked some of them to cross-check students' information, Therefore, the students were able to learn how to give appreciation to contextually. The students seemed to have the same characters which imitate as the teacher instruction. The researcher took four students as the representative of the whole students. So that, in this activity described that the students already imitated teacher instruction in which interact with one another to get their friends opinion toward the picture. Second, it is shown in second observation on Tuesday, July 15th, 2019, after the teacher instructed the students toward the implementation of asking and giving appreciation, the students seemed to walk around suitable with the teacher instruction. The students should ask their friends about their opinion towards the picture and ask their friend to sign it on the book as the mark that they had asked their friends' opinion, the activity The researcher took four students as the representative of the whole students. So that, in this activity described that the students already imitated teacher instruction in which interact with one another to get their friends opinion toward the picture.

The third, it is shown in third observation on Monday, July 22nd, 2019. The researcher argued this activities was not special, teacher just asked the student answer the question on the book. It was different with the previous activity that asked the students collected the information during the implementation. But it had its own challenging, students must answer the question which divided into 6 part of question correctly within 30 minutes.

Then, the researcher found several students who could not do the question immediately because of the limitations of the existing book. So it defined that students did not interest this motor reproduction indirectly. Students could not improve their skill to get any direct information while they just were asked to do the question belongs to the book. In other side, students still could strengthen their memories in the pattern of tenses learned in that day, such as arranging, chose the correct answer through multiple choice, and other instruction that already written on the book.

Therefore, according to the descriptive above it could be concluded that the indicators of students' motor reproduction appeared at this class, in which proved by the students who practiced it at classroom after teacher modeling them, the students were able to imitate or implemented-well the task during activity. It showed that all students were totally dominant ask and give their

opinion while getting the information correctly.

\section{Reinforcement}

This activity was conducted to motivate students to do better even though through punishment or give a reward. The students showed good respect after being motivated by their teacher it could be described as follow: First, it showed the 
observation on all meetings, when the teacher warned the students in which students who made crowded, sleeping, or someone who made him interested will be chosen by the teacher to answer the teacher's questions. All students seemed directly quiet in which they were afraid to answer the teacher's question. But the teacher had another option, that is, the students who made him interested, they must answer it. Therefore, it expected to improve students intention to focus and enthusiastic in studying English which means did not make a noisy situation or something else. Second, it showed the observation on all meetings, after the teacher asked the students who related the material, the teacher gave them appreciation within the reward of motivation. The students seemed happy after it, so it was good for students so they were not afraid anymore and enjoy the activity even though the teacher asked them then.

Therefore, according to the descriptive above it could be concluded that the indicators of students' reinforcement appeared at this class, in which proved by most students who were getting punishment or reward during the activity, it would improve their inside characters so that all students were totally motivated after getting the reinforcement after it.

\section{INTERVIEW}

From the result of the interview related to social learning, the researcher asked the teacher at the last meeting after conducting the observation in each meeting. According to the result of interviewing the teacher, it could be concluded that all indicators in studying English for 8th grade students in social learning conducted well on July 15th, 2019. The teacher's answer could be used as additional data which needed in this research, meanwhile there was correlation regarding student's social learning which included attention process, retention process, motor reproduction process, and also reinforcement process regarding the material of asking and giving appreciation expressively.

\section{Conclusion And Suggestion}

According to the descriptive of observation and interview data above, it can be concluded that all items within social learning involve studying English seem dominantly at the classroom. Because from 4 observational process items which are consist of attention, retention, motor reproduction, and reinforcement were totally implemented by 8th-grade students. The indicators show in every process such as teacher explained the material, teacher told the instruction, then the students showed variety responses, such as they were looking at the teacher, write and take a note on their book, imitate the teacher slowly, ask teacher if they do not understand that involve the attention process, implementation through interaction in getting information due the assignment, and look enthusiastic after the teacher motivate them toward their learning. Moreover, this observation data was strengthened by the result of the teacher's interview by following question items that already delivered to him. So that social learning for 8th-grade students on studying English appeared in the classroom practice at SMP Muhammadiyah 12 GKB. Based on the finding and conclusion of this study, there are some suggestions that provide for the students, teacher, and future researcher who want to analyze regarding social learning. The suggestion as follow: Firstly, for teacher: they should be understood with their students deeply, because students can be optimized their learning practice through social learning. Secondly, for students: they should be care with their study which is discipline while teaching and learning activity. The third, for researcher: we suggests for further researcher to conduct social learning for different level on studying English because it can be known every single character who is going to learn through observational, imitation, and modelling.

\section{References}

Akujobi, C.T and Jack, Jackson T.C.B (2017): Social Change and Social Problems. In Abasiekong, E.M, Sibiri, E.A, Ekpenyong, N.S (eds.) Major Themes in Sociology: An Introductory Text. pp 491-526. Benin City, Mase Perfect Prints.

Tarsono. (2010). Implikasi Teori Belajar Sosial (Social Learning Theory)Dari Albert Bandura DalamBimbingan Dan Konseling. Psympathic, Journal Ilmiah Psikologi. Vol. III, No. 1:29-36

Jenna, M. S. \& Anna, M. S. (2018).

Learning from ELLs' Perspectives: Mismatch between ELL and teacher perspectives on ELL Learning Experiences. English Language Teaching. Vol. 11 (01).

S, Deaton. (2015). Social Learning Theory In The Age Of Social Media: Implications For Educational

Practitioners. I-Manager's Journal of

Educational Technology. Vol. 12, No. 01.

De Angelis, G., \&Dewaele, J. M. (2009).

The development of psycholinguistic research on cross linguistic

influence. In L. Aronin, \& B. Hufeisen (Eds.), The exploration of multilingualism(pp. 63-77). Amsterdam,Netherlands: John Benjamins.https://doi.org/10.1075/aa 1s.6.04ch4 
M. Phil. (2018). Difficulties of Learning English Language at the Secondary Level: A Case Study of Thakuragaon District. Journal of Education and Training. Vol. 5 (2).

NEISSER, U. (1967). Cognitive psychology.

New York: Appleton-Century- Crofts, Krashen, S. D. (1982/2009). Principles and practice in second language acquisition. Oxford,

UK: Pergamon.

Cummins, J. (1979). Linguistic interdependence and the educational development of bilingual children. Review of Educational Research,

49(2), 222-

251.https://doi.org/10.3102/0034654

3049002222

Cummins, J. (2000). Language, power and pedagogy: Bilingual children in the crossfire. Clevedon, UK:Multilingual Matters.

Piaget, J. (1985). The equilibration of cognitive structures: The central problem of intellectual development. Chicago, IL: University of Chicago Press

Alexander, V., Luca, P., \& Giorgio, C. (2018). The Role of Intelligence in Social Learning, Scientific Report. 10 ,

Mark. S. R., Anna C., Giorgina C. Evely, Georgina C., Ioan F., Jayne G., Adele L., Jens N., Brad P., Christina P., Chris R., \& Lindsay C. S. (2006).

The Importance of Social Learning

in Restoring the Multifunctionality of Rivers and Floodplains. Ecology and Society. 10.

Walter, M. (1973). Toward A Cognitive Social Learning Reconceptualization Of Personality.Psychological review. Vol 80 (32). 252-283.

Zdep, S., \& Irvine, S. (1970). A reverse Hawthorne effect in educational evaluation. Journal of SchoolPsychology, 8(2), 89. https://doi.org/10.1016/00224405(70)90025-7

Peregoy, S., \& Boyle, F. (2008). Reading, writing and learning in ESL: A resource book for k-12 teachers (5th-ed.). Boston, MA: Allyn \& Bacon.

Firestone, W. A., \& Rosenblum, S. (1988).

Building commitment in urban schools Educational Evaluation and Policy Analysis, 10, 285-300.

Peregoy, S., \& Boyle, F. (2008). Reading, writing and learning in ESL: A resource book for $k$-12 teachers (5th ed.). Boston, MA: Allyn \& Bacon.

Purwanto, Ngalim. (2006).

Psikologi Pendidikan. Bandung: PT Remaja Rosdakarya. Suprijono, Agus. (2012). Cooperative

learning. Yogyakarta: PustakaPelajar. 